\title{
EFFECTIVENESS OF MASTER PROGRAM: A CASE STUDY OF PRITHIVI NARAYAN CAMPUS, T.U, POKHARA
}

\author{
Keshar J. Baral
}

\begin{abstract}
This paper examines the effectiveness of Master programs run in Prithivi Narayan Campus (PNC) from both financial and academic perspectives. None of the programs is cost effective. Overall, cost recovery rate is very low, and cost of higher education measured in term of cost per student is refatively high. None of the Master programs excepting the Sociology and Anthropology (wilt henceforth be mentioned as Sociology) is financially sustainable. Academic performance in term of pass percent is not satisfactory. Thus, this paper will provide T.U. authority the valuable information for right course of future decision to make the Master program more effective in its constituent campuses.
\end{abstract}

\section{INTRODUCTION}

PNC was established in 1960 with a very limited number of teachers, students, and staff. In its inception, there were only 2 teachers, 2 administrative staff, and 13 students. Now it has emerged as a leading higher education institution in the Western Development Region. It has more than ten thousand aspirants in different five faculties-management, education, humanities, science, and law. At present, it is running intermediate and bachelor classes in all these faculties except in law in day shift. There is Bachelor program in management, humanities, education, and law in the morning shift. Master program also runs in management, education, sociology, economics, political science, history, mathematics, English, and Nepali in the same shift. However, the question is arising on the justification and effectiveness of Master program in some subjects and Bachelor program in law. T.U. and campus administration never evaluates the effectiveness of their programs. They do not attempt to justify the expenditure from national exchequer on these programs. So, the thrust of this paper is to draw the attention of T.U. authority and campus administration to the performance and justification of these programs.

\section{METHODOLOGY}

This study is based on the cross section data of the academic year 2002/03. Cost recovery rate, cost per input, and cost per output have been used to measure the financial effectiveness of the programs. Similarly, the academic performance has been measured in terms of pass percent in the annual examination.

The Mann-Whitney's $U$ test and Kruskal-Wallis's test have been used to analyse the inter-department performance and rank the departments respectively. 
For these tests, population has been defined in terms of the students filling out the examination form. After preparing the sampling frame, $25 \%$ sample was drawn using the Select Case Random Sampling procedures of SPSS.

\section{Calculation of Revenue}

For calculating the cost recovery rate, first, gross revenue is worked out. It is worked out by multiplying the total number of students admitted in each department by the total charges paid by each student in each year-first and second year. The total annual charges include student union magazine charge, sport development fee, student union fee, student welfare fee, and library deposit.' It also includes examination fee, department development fee, campus development fee, and tuition fee. In general, student union, on its discretion, uses the revenue raised from different sources such as union magazine, sport development fee, student union fee, etc. Some of the departments like Sociology, Mathematics, and English raise the funds from department development fee. They use them on their discretion:- Similarly, campus administration can use only the funds raised from campus development fee and tuition fee as a part of the allocated T.U. budget. Therefore, revenue raised from tuition fee and campus development fee are included in the net revenue. In addition, tuition fee paid by $20 \%$ of total admitted students is deducted to arrive at the net revenue. In short, the following models are used to work out the gross and net revenue raised from the Master students:

$$
\begin{aligned}
& R_{g}=N_{s} X \\
& R_{n}=R_{g}-R_{e} \\
& R_{c}=N_{s} S_{1}+N_{s} S_{s}+N_{s} S_{3}+N_{s} S_{4}+N_{s} S_{5}+N_{s} E+.2 N_{s} F_{1}+N_{s} D
\end{aligned}
$$

Where

$R_{\mathrm{g}}=$ gross revenue

$X=$ total annual charges

$R_{n}=$ net revenue

$R_{e}=$ total revenue that campus administration can not use on its discretion

$\mathrm{N}_{\mathrm{s}}=$ number of student admitted in each year of each department/faculty

$S_{1}=$ charge for student union magazine, Machhapuchre (per student)

$\mathrm{S}_{2}=$ sport development fee (per student)

$\mathrm{S}_{3}=$ student union fee (per student)

$\mathrm{S}_{4}=$ student welfare fee (per student)

$S_{5}=$ library deposit (per student)

$E=$ annual examination fee (per student)

$F_{1}=$ tuition fee (per student)

$\mathrm{D}=$ department development fee (per student) 


\section{Calculation of Direct Operation COST}

First, total weekly load was investigated to work out the operation cost of each Master program run in PNC. This was done by means of the class routine of the academic year 2002/03. Then, the workload, status, and nature of assignment-regular assignment or part time assignment-of each teacher involved in Master program was investigated. Finally, total remuneration of each teacher involved in Master program was extracted from the campus payroll. Thus, the basic information-weekly workload, teacher status, nature of assignment and remuneration-were extracted from the official records of the campus. The calculation of the operation cost is based on (i) 150 operating days, (ii) Rs. 75/remuneration per period for Master level, (iii) mandatory weekly workload ratio between Master level (12 periods) and Bachelor (15 periods). ${ }^{2}$ The following models are used to allocate the remuneration of teacher teaching in both Bachelor and Master prograns:

$$
\begin{aligned}
& R_{S . I}=R_{l} L_{D} \quad \quad \ldots \quad \ldots \quad \ldots \\
& R_{p}=\frac{\left[\frac{R_{j}}{\left\{\left(L_{D}\right) W_{D}+\left(L_{B}\right) W_{B}\right\}}\right]\left(L_{D}\right) W_{D}}{} \ldots \\
& R_{. J}=\sum_{m=1}^{13} S_{m}+\sum_{m=1}^{12} P F_{m} \quad \ldots \quad \ldots \quad \ldots
\end{aligned}
$$

Where,

$R_{S J}=$ remuneration of $j^{t h}$ teacher allocated to the $s^{\text {th }}$ subject in Master program

$R_{P}=$ pro rata per period remuneration for teaching any subject in Master program

$L_{D}=$ total workload (measured in terms of total period in an academic year)

of $\mathrm{j}^{\text {th }}$ teacher in Master program

$\mathrm{R}_{\mathrm{j}}=$ total annual remuneration of $\mathrm{j}^{\text {th }}$ teacher

$\mathrm{W}_{\mathrm{D}}=$ weight for workload in Master program (.56)

$\mathrm{L}_{\mathrm{B}}=$ total workload (measured in terms of total period in an academic year)

of $\mathrm{j}^{\text {th }}$ teacher in Bachelor program

$\mathrm{W}_{\mathrm{B}}=$ =weight for workload in Bachelor program (.44)

$\mathrm{m}=$ month

$S=$ monthly salary

$\mathrm{PF}=$ provident fund

The extra remuneration per period was increased to Rs.150 effective with Magh 1, 2060. The weekly workload was decreased to 12 and 15 period in Master, and Bachelor and Certificate levels on Bhadra 30, 2057 ( vide the decision number 974 of Executive Council, T.U.).

In the case of the part time teacher, $R_{p}$ is equal to $R s .75$. 


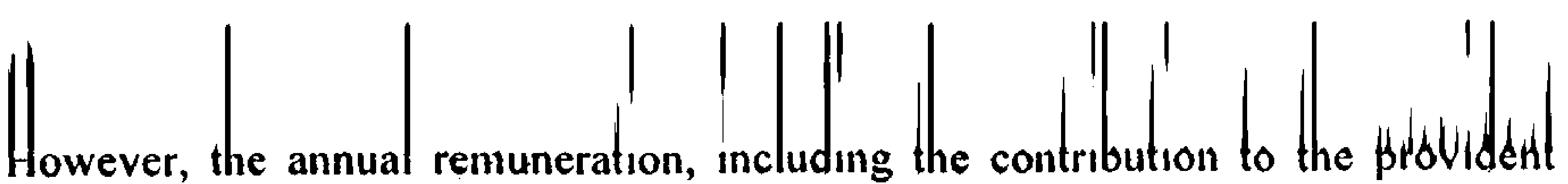
fund on the part of T.U. and allowance for Dashain, of full time teacher teaching only in Master program has been allocated to the program of the respective year.

The following model (3.1) and model (3.2) are used to calculate the total operation cost exclusive to the salary and allowances of administrative staff, and inclusive to salary and allowances of administrative staff (henceforth be referred by administrative overhead), respectively:

$$
\begin{array}{llll}
E W O=\sum_{j=1}^{n} D_{j, s} & \ldots & \ldots & \ldots \\
E W T O=\frac{E W O}{(1-r)} & \ldots & \ldots & \ldots
\end{array}
$$

Where

Djs $=$ remuneration of $\mathrm{j}^{\text {th }}$ teacher allocated to $s^{\text {th }}$ subject in Master program

EWO=total operation cost of Master program exclusive of administrative overhead

$\mathrm{n}=$ number of teachers teaching in Master program

EWTO=total operation cost inclusive of administrative overhead

$r=$ ratio of administrative overhead to total operation cost. For the fiscal year $2002 / 03$, it is $20 \%$.

\section{Per Period Operation CoSt}

Two types of per period operation cost-exclusive and inclusive of administrative overhead-are worked out. Per period operation cost exclusive of administrative overhead $\left(E W O_{P}\right)$ and inclusive of administrative overhead $\left(E_{W T O}\right)$ are worked out by using the following models:

$$
\begin{aligned}
& E W O_{1}=\frac{E W O}{\sum_{S=1}^{n} L_{D S}} \quad \ldots \quad \ldots \quad \ldots \\
& E W T O_{p}=\frac{E W T O}{\sum_{Y=1}^{n} L_{D S}} \quad \ldots \quad \ldots \quad \ldots
\end{aligned}
$$

Where

$\mathrm{L}_{D S}=$ total annual period of $s^{\text {th }}$ subject in a particular program and year $\mathrm{n}=$ number of subject

EWO and EWTO denote as in model (3.2) 


\section{INPIT AND OITPUT COST}

Two types of input, and output cost-one based on EWO and next on EWTO-are worked out. The following models are used to calculate these costs:

$$
\begin{array}{llll}
E W O_{1}=\frac{E W O}{N_{s}} & \ldots & \ldots & \ldots \\
E W O_{0}=\frac{E W O}{N_{P}} & \ldots & \ldots & \ldots \\
E W T O_{1}=\frac{E W T O}{N_{s}} & \ldots & \ldots & \ldots \\
E W T O_{O}=\frac{E W T O}{N_{p}} & \ldots & \ldots & \ldots
\end{array}
$$

Where

$E_{W}=$ per input cost based on EWO

$\mathrm{EWO}_{\mathrm{O}}=$ per output cost based on EWO

$\mathrm{EWTO}_{1}=$ per input cost based on EWTO

$\mathrm{EWTO}_{\mathrm{O}}=$ per output cost based on EWTO

$N_{p}=$ number of regular student getting through the annual examination, and

$\mathrm{N}_{S}$, and EWO and EWTO denote as in model (1.1), and (3.2) respectively.

\section{COST RECOVERY RATE}

It indicates the extent to which revenue raised from students covers the operation çost of the program. It is measured by the ratio of revenue raised from students to total operation cost. Here, cost recovery rates based on $R_{\mathrm{g}}$ and $\mathrm{R}_{\mathrm{n}}$, and EWO and EWTO have been worked out. The following models are used to work out these measures of cost recovery rate for Master program:

$$
\begin{array}{llll}
C R R_{g}=\frac{R_{g}}{E W O} \times 100 & \ldots & \ldots & \ldots \\
C R R_{\prime \prime}=\frac{R_{n}}{E W O} \times 100 & \ldots & \ldots & \ldots \\
C R R_{g \prime}=\frac{R_{g}}{E W T O} \times 100 & \ldots & \ldots & \ldots \\
C R R_{m}=\frac{R_{n}}{E W T O} \times 100 & \ldots & \ldots & \ldots
\end{array}
$$


Wheple

$$
\begin{aligned}
& C R R_{\mathrm{g}}=\text { gross cost recovery rate based on EWO } \\
& C R R_{\mathrm{n}}=\text { net cost recovery rate based on EWO } \\
& \mathrm{CRR}_{\mathrm{gt}}=\text { gross cost recovery rate based on EWTO } \\
& C R R_{\mathrm{nt}}=\text { net cost recovery rate based on EWTO }
\end{aligned}
$$

$R_{b}, R_{n}, E W O$, and EWTO denote as in model (1.1), (1.2), (3.1), and (3.2) respectively.

\section{ANALYSIS OF EXPENDITURE AND REVENUE}

\section{REVENUE ANALYSIS}

According to the principle of cost recovery system, the main source of the revenue of educational institutions should be students. $\mathrm{HMG} / \mathrm{Nepal}$ has adopted the cost recovery principle in higher education (NPC, 2002). However, the main source of revenue of T.U. is national exchequer. T.U. is imparting higher education, in absolute term, at lower cost with the standpoint of student and parents. But it is costlier to the nation. The Master students do not have to pay the tuition fee as much as the nursery students of private school do. T.U. has empowered its constituent campuses to-impose the additional fee like campus development fee, library development fee, department development fee etc. PNC also has imposed campus development fee. Some departments like English and Mathematics have charged the department development fee to the Master students. On average, the Master students have paid Rs.4, 400 and Rs. 1,513 at the time of admission in the first year and the second year respectively. The total annual charges that a student has to pay at the time of admission in the first year ranges from Rs. 1,580 to Rs.6,100. In the second year, it does from Rs. 1,505 to Rs.1,680. The high variation in the total charges in the first year is mainly due to the campus development and department development fee.

PNC has two types of Master programs-program financed by T.U. and program run with local resources. Out of nine Master programs, ${ }^{4}$ Master in Geography and Master in Economics are financed by T.U. The rest of the programs are supposed to run with local resources. So, the students admitted in the programs, which are dependent on such resources, have to pay campus development fee in the first year. In addition to this, students of Mathematics, English, and Sociology have to pay department development fee. The concerned departments expend the revenue raised from department development fee for seminar, workshop, books, and journals. As stated earlier, the campus can not appropriate the revenue raised from student union magazine, sport development fee, and student union fee. It is also not allowed to spend student welfare fee, library deposit, annual examination fee, and department development fee. So, revenue has been worked out by including and excluding the revenue raised from these sources.

At present. it has 10 Master programs. In the academic year 2003/04, it has added Master program in Education. But this newly run program has not been included in this study. 
Table 1: Revenue raised from students in the fiscal year 2002/03

\begin{tabular}{|c|c|c|c|c|c|c|}
\hline \multirow[t]{2}{*}{ Subject } & \multicolumn{2}{|c|}{ First Year } & \multicolumn{2}{|c|}{ Second Year. } & \multicolumn{2}{|l|}{ Total } \\
\hline & Gross & Net & Gross & Net & Gross & Net \\
\hline English & 295.020 & 153,995 & 79,765 & 41,150 & 374,785 & 195145 \\
\hline Nepali & 111,720 & 76,145 & 36,120 & 18,620 & 147,840 & 94765 \\
\hline Economics & 67.940 & 36,555 & 52,675 & 27,370 & 120,615 & 63925 \\
\hline Geography & 12,285 & 7.520 & 20,160 & 11,780 & 32,445 & 19300 \\
\hline History & 29.640 & 19.945 & 13,545 & 6,890 & 43,185 & 26835 \\
\hline Sociology & 2.848 .700 & 727,415 & - & - & $2,848,700$ & 727415 \\
\hline Math & 32.780 & 17.275 & 30,100 & 15,640 & 62.880 & 32915 \\
\hline Management & 360,240 & 245,710 & 132,440 & 68,520 & 492,680 & 314230 \\
\hline $\begin{array}{l}\text { Political } \\
\text { Science }\end{array}$ & 34,200 & 23,355 & 31,605 & 16,570 & 65,805 & 39925 \\
\hline Total & $3,792,525$ & $1,307,915$ & 396,410 & 206,540 & $4,188,935$ & 1514455 \\
\hline
\end{tabular}

Source: Appendix 2.

Sociology students have contributed more than $50 \%$ of both gross and net revenue raised from Master program. This is mainly due to the swelling number of students, campus development fee, and department development fee. The difference between the gross revenue and net revenue shows that the campus administration can use only around $36 \%$ of the revenue raised from the students for recurrent expenditures.

\section{OPERATION COST}

In the observed fiscal year, total operation cost of PNC was Rs.53,713,381.24. Out of this, Rs.49, 181,355.73 was salary and allowances of teachers and administrative staff. This comes around $92 \%$ of total operation cost of the campus. Thus, other components of operation cost-teaching materials, maintenance, utilities etc., are negligible. So, salary and allowances have been considered as a proxy of the operation cost of the Master programs.

As stated earlier in Methodology, operation cost is based on the total annual remuneration, workload, status of assignment, and weight assigned to the weekly workload in Bachelor and Master Programs. Salary and allowances of teachers involved in the concerned Master program have been allocated to the concerned program. EWO refers to the allocated salary and allowances of teachers to the concerned program. Thus, EWO is the cost of 


\section{If EFFECTIVENESS OF MASTER PROGRAMi}

Table 2: Subject-wise operation cost in the fiscal year 2002/03

\begin{tabular}{|c|c|c|c|c|c|c|}
\hline \multirow[t]{2}{*}{ Subject } & \multicolumn{2}{|c|}{ First Year } & \multicolumn{2}{|c|}{ Second Year } & \multicolumn{2}{|c|}{ Total } \\
\hline & EWO & EWTO & EWO & EWTO & EWO & EWTO \\
\hline English & 233,082 & 291,353 & 255,479 & 319,348 & 488,561 & 610,701 \\
\hline Nepali & 355,186 & 443,982 & 472,270 & 590.337 & 827,456 & $1,034,319$ \\
\hline Economics & 981,259 & $1,226,574$ & 685,145 & 856,432 & $1,666,404$ & $2,083,006$ \\
\hline Geography & 660,189 & 825,236 & 600,377 & 750,472 & $1,260,566$ & $1,575,708$ \\
\hline History & 576,720 & 720,900 & 406.605 & 508.256 & 983,325 & $1,229,156$ \\
\hline Sociology & 198,131 & 247,664 & - & - & 198,131 & 247,664 \\
\hline Math & 306,587 & 383,264 & 302,459 & 378.073 & 609,046 & 761,337 \\
\hline Managenrent & 300.156 & 375,195 & 680,640 & 850,800 & 980,796 & $1,225,995$ \\
\hline Political Science & 466,755 & 583.444 & 505,373 & 631.717 & 972.128 & $1,215,161$ \\
\hline Total & $4,078,1165$ & $5,097,612$ & $3,908,348$ & $4,885,435$ & $7,986,413$ & $9,983,047$ \\
\hline
\end{tabular}

Source: Derived from Model (3.1) and (3.2).

academic manpower directly involved in each Master program. This represents, albeit there are many elements of operation cost, direct operation cost of each program. The second measure of operation cost (EWTO) has been worked out by adjusting administrative overhead.

EWO statistics imply that there is an asymmetry in the assignment status, status of teachers involved in the program and distribution of the workload across the programs. Master program in Economics is the most expensive. This is because of the involvement of the senior teac[hers with relatively less workload. Moreover, most teachers were assigned on full time basis. In Economics, out of 13 teachers, 11 are involved only in Master program and one in both Master and Bachelor.

Sociology has the least operation cost in the observed academic year. This is because of the assignment of the load on part time basis. Almost all teachers involved in the Master program are working on part time basis. Workload even to the full time teachers was assigned on part time basis. Similarly, in English, relative to other subjects, the number of workload assigned on part time basis is greater. This is the reason why this program has relatively low operation cost. Thus, campus has run some of the Master programs at minimum cost and some at higher cost. 
Table 3: Subject-wise per period operation cost in the fiscal year 2002/03

\begin{tabular}{|c|c|c|c|c|c|c|}
\hline \multirow[t]{2}{*}{ Subject } & \multicolumn{2}{|c|}{ First Year } & \multicolumn{2}{|c|}{ Second Year } & \multicolumn{2}{|l|}{ Total } \\
\hline & $E W O_{p}$ & $\mathrm{EWTO}_{\mathrm{p}}$ & $\mathrm{EWO}_{\mathrm{p}}$ & $\mathrm{EWTO}_{\mathrm{p}}$ & $\mathrm{EWO}_{\mathrm{P}}$ & $\mathrm{EWTO}_{\mathrm{p}}$ \\
\hline English & 311 & 388 & 341 & 426 & 326 & 407 \\
\hline Nepali & 474 & 592 & 525 & 656 & 501 & 627 \\
\hline Economics & 935 & 1,168 & 914 & 1,142 & 926 & 1,157 \\
\hline Geography & 734 & 917 & 801 & 1,001 & 764 & 955 \\
\hline History & 641 & 801 & 542 & 678 & 596 & 745 \\
\hline Sociology & 88 & 110 & - & - & - & - \\
\hline Math & 409 & 511 & 403 & 504 & 406 & 508 \\
\hline Management & 445 & 556 & 478 & 597 & 467 & 584 \\
\hline Political Science & 622 & 778 & 562 & 702 & 589 & 736 \\
\hline Total & 465 & 581 & 573 & 716 & 512 & 640 \\
\hline
\end{tabular}

Source: Derived from Model (4.1) and (4.2).

There is a great variation in per period operation cost across the subjects. It is the least in Sociology, and greatest in Economics. The reason behind the least operation cost in Sociology is the nature of the assignment of the workload. Almost all workloads in this program were assigned on part time basis. On average, campus has incurred Rs.465 per period in the first year and Rs. 573 in the second year. In general, operation cost per period in the first year is greater than in the second year.

Table 4: Input and output operation cost in the fiscal year 2002/03

\begin{tabular}{|c|c|c|c|c|c|c|c|c|}
\hline \multirow[t]{3}{*}{ Subject } & \multicolumn{4}{|c|}{ First Year } & \multicolumn{4}{|c|}{ Second Year } \\
\hline & \multicolumn{2}{|c|}{ Input } & \multicolumn{2}{|c|}{ Output } & \multicolumn{2}{|c|}{ Input } & \multicolumn{2}{|c|}{ Output } \\
\hline & $\mathrm{EWO}_{1}$ & EWTO & $\mathrm{EWO}_{0}$ & $\begin{array}{l}\text { EWTO } \\
0\end{array}$ & $\mathrm{EWO}_{1}$ & $\begin{array}{l}\text { EWTO } \\
1\end{array}$ & $E W O_{0}$ & EWTO $_{0}$ \\
\hline English & 2,354 & 2,943 & * & * & 4,820 & 6,025 & 85,160 & 106,449 \\
\hline Nepali & 7,249 & 9.061 & 88,797 & 110,996 & 19,678 & 24,597 & 52,474 & 65,593 \\
\hline Economics & 22,820 & 28,525 & $*$ & * & 19,576 & 24,469 & 685,145 & 856,432 \\
\hline Geography & 94,313 & 117,891 & 220,063 & 275,079 & 50,031 & 62,539 & 60,038 & 75,047 \\
\hline History & 44,363 & 55,454 & 576,720 & 720,900 & 45,178 & 56,473 & 81,321 & 101,651 \\
\hline Sociology & 424 & 530 & 13,209 & 16,511 & + & + & + & + \\
\hline Math & 27.872 & 34,842 & * & * & 15,123 & 18,904 & 100,820 & 126,024 \\
\hline $\begin{array}{l}\text { Management } \\
\text { Political }\end{array}$ & 1,900 & 2,375 & 75,039 & 93,799 & 7,735 & 9,668 & 32,411 & 40,514 \\
\hline Science & 31,117 & 38,896 & 93,351 & 116,689 & 24,065 & 30,082 & 72,196 & 90,245 \\
\hline Total & 4,731 & 5,914 & 127,440 & 159,300 & 14,917 & $\mathbf{1 8 , 6 4 7}$ & 66,243 & 82,804 \\
\hline
\end{tabular}

Source: Derived from model (5.1), (5.2), (5.3), and (5.4).

* Result is nil.

+ Program was run in the academic year 2002/03. 
In addition to the per period operation cost, operation cost has been measured in term of inputs and outputs. ${ }^{5}$ Sociology has the least input cost in the first year. Input cost in Geography is the greatest one. This is attributed to too small number of students and involvement of senior and full time faculties. In the same manner, input cost without overhead is relatively high in Economics, History, Mathematics, and Political Science. The main reason behind this phenomenon is the small number of students.

In general, operation cost per student in the second year should be higher than in the first year mainly due to the high drop out rate. The drop out rates in Master program of Humanity, Management, and Science in the academic year $2002 / 03$ are $42.44 \%, 44.3 \%$, and $52.38 \%$ respectively (Baral, 2004). In the second year, per student operation cost in English, Nepali, History, and Management is higher than it is in the first year. In Economics, Geography, Political Science, and Mathematics, it is lesser than it is in the first year. This is not because of the reduction in the operation cost and drop out rate but because of the decreasing trend of student admission of these subjects in the first year.

Number of students admitted in some subjects like Geography, History, Mathematics, and Political Science does not justify the program. In these subjects, student number is dwindling year by year. Senior faculties are being engaged in the program for handful students on the one hand and on the other, scarce resources of the campus are being wasted. Due to the high wastage rate, production cost is very high. On an average, campus has incurred unimaginable cost for one student getting through the final examination of each year. In some subjects like English, Economics and Mathematics, operation cost has gone sour in the results. Relative to other subjects excepting Sociology, Management is a little more cost effective in both years. But the case of Sociology. is just window dressing. It seems the most cost effective but in reality it is not. It is only due to the employment of part time teachers and assignment of workload even to a full time teacher on part time basis. The output cost in the second year is lesser than it is in the first year. This implies that teaching and learning process in the second year is more effective and efficient than in the first year. But this is not due to the improved teaching and learning class environment, but due to a little bit seriousness on the part of the students in their studies.

\section{COST RECOVERY RATE}

Master programs, other than Geography and Economics, are supposed to be financially self sustainable. Firstly, revenue raised from the student should cover at least the salary and allowances of the teachers involved in the program. Secondly, it should cover the administrative expenses. So, in this perspective, cost recovery rate has been worked out using two measures-operation cost exclusive to administrative overhead and operation cost inclusive of administrative overhead - of operation cost.

5 Here, input refers to the number of students admitted in each year and output does to the number of students who pass the examination of the respective year. 
In the first year, the range of gross cost recovery rate $\left(C^{2} R_{\mathrm{g}}\right)$ based on the operation cost exclusive of administrative overhead across the subjects is very wide. It ranges from $1.86 \%$ to $1437.79 \%$. It is unusually high in Sociology mainly due to the swelling number of students, involvement part time teachers and department development fee. In English, it is high mainly because of the involvement of the part time teachers and department development fee.

Table 5: Cost recovery rate in the fiscal year 2002/03 (based on EWO)

\begin{tabular}{lrrrrrr}
\hline Subject & \multicolumn{2}{c}{ First Year } & \multicolumn{2}{c}{ Second Year } & \multicolumn{2}{c}{ Total } \\
\cline { 2 - 8 } & \multicolumn{1}{c}{$\mathrm{CRR}_{\mathrm{g}}$} & \multicolumn{1}{c}{$\mathrm{CRR}_{\mathrm{n}}$} & \multicolumn{1}{c}{$\mathrm{CRR}_{\mathrm{g}}$} & \multicolumn{1}{c}{$\mathrm{CRR}_{\mathrm{n}}$} & \multicolumn{1}{c}{$\mathrm{CRR}_{\mathrm{g}}$} & \multicolumn{1}{c}{$\mathrm{CRR}_{\mathrm{n}}$} \\
\hline \hline English & 126.57 & 66.07 & 31.22 & 16.11 & 76.71 & 39.94 \\
Nepali & 31.45 & 21.44 & 7.65 & 3.94 & 17.87 & 11.45 \\
Economics & 6.92 & 3.73 & 7.69 & 3.99 & 7.24 & 3.84 \\
Geography & 1.86 & 1.14 & 3.36 & 1.96 & 2.57 & 1.53 \\
History & 5.14 & 3.46 & 3.33 & 1.69 & 4.39 & 2.73 \\
Sociology & 1437.79 & 367.14 & - & - & 1437.79 & 367.14 \\
Math & 10.69 & 5.63 & 9.95 & 5.17 & 10.32 & 5.40 \\
Management & 120.02 & 81.86 & 19.46 & 10.07 & 50.23 & 32.04 \\
Political Science & 7.33 & 5.00 & 6.25 & 3.28 & 6.77 & 4.11 \\
\hline \multicolumn{1}{c}{ Total } & $\mathbf{9 3 . 0 0}$ & $\mathbf{3 2 . 0 7}$ & $\mathbf{1 0 . 1 4}$ & $\mathbf{5 . 2 8}$ & $\mathbf{5 2 . 4 5}$ & $\mathbf{1 8 . 9 6}$ \\
\hline \hline
\end{tabular}

Source: Table 1 and Table 2.

In Management, it is because of the sizeable number of students. In the gross term, campus is not able to recover the operation cost of the Master program in almost all subjects in the first year. In the second year, it is not able to recover even the salary and allowances of teachers involved in the program.

$\mathrm{CRR}_{\mathrm{g}}$ may be a misnomer to the concerned authority. At a glance, authority may have misconception about it. Recovery rate based on the net revenue $\left(C R R_{n}\right)$ is the correct measurement of financial sustainability of the program. $C R R_{n}$ of any subject does not imply the financial sustainability of the program. It suggests that none of the Master programs excepting Sociology is financially sustainable. Further, it implies that alt are being run at the cost of Bachelor and Intermediate programs. Sociology also will not recover its operation cost after employing the full time teachers provided the present fee structure and $d$ windling number of students in the first year.

Foregoing cost recovery analysis is based on the operation cost exclusive of the administrative overhead. In other word, it analyzed the cost recovery rate in the prospective of recovering the salary and allowances of teachers involved in the Master programs. It is desirable to analyse the cost recovery rate based on the operation cost inclusive of the administrative overhead. 
Table 6: Cost recovery rate in the fiscal year 2002/03 (based on EWOT)

\begin{tabular}{lrrrrrr}
\hline \multirow{2}{*}{ Subject } & \multicolumn{2}{c}{ First Year } & \multicolumn{2}{c}{ Second Year } & \multicolumn{2}{c}{ Total } \\
\cline { 2 - 8 } & \multicolumn{1}{c}{ CRR $_{\mathrm{gt}}$} & \multicolumn{1}{c}{$\mathrm{CRR}_{\mathrm{nt}}$} & \multicolumn{1}{c}{$\mathrm{CRR}_{\mathrm{gt}}$} & $\mathrm{CRR}_{\mathrm{m}}$ & $\mathrm{CRR}_{\mathrm{gt}}$ & \multicolumn{1}{c}{$\mathrm{CRR}_{\mathrm{mt}}$} \\
\hline English & 101.26 & 52.86 & 24.98 & 12.89 & 61.37 & 31.95 \\
Nepali & 25.16 & 17.15 & 6.12 & 3.15 & 14.29 & 9.16 \\
Economics & 5.54 & 2.98 & 6.15 & 3.20 & 5.79 & 3.07 \\
Geography & 1.49 & 0.91 & 2.69 & 1.57 & 2.06 & 1.22 \\
History & 4.11 & 2.77 & 2.66 & 1.36 & 3.51 & 2.18 \\
Sociology & 1150.23 & 293.71 & - & - & 1150.23 & 293.71 \\
Math & 8.55 & 4.51 & 7.96 & 4.14 & 8.26 & 4.32 \\
Management & 96.01 & 65.49 & 15.57 & 8.05 & 40.19 & 25.63 \\
Political Science & 5.86 & 4.00 & 5.00 & 2.62 & 5.42 & 3.29 \\
\hline \multicolumn{1}{c}{ Total } & $\mathbf{7 4 . 4 0}$ & $\mathbf{2 5 . 6 6}$ & $\mathbf{8 . 1 1}$ & $\mathbf{4 . 2 3}$ & $\mathbf{4 1 . 9 6}$ & $\mathbf{1 5 . 1 7}$ \\
\hline
\end{tabular}

Source: Table 1 and Table 2.

The overall net cost recovery rate is around 15\%. Master programs in Geography, History, Economics and Political Science, Mathematics are very poor with the standpoint of cost recovery rate. Excepting Sociology, cost recovery rate in Management, English and Nepali is a little bit better than in other subjects, but not satisfactory. Statistics on cost recovery rate given in both Table 5 and Table 6 suggest that none of the Master programs excepting Sociology is recovering the operation cost albeit most of them are supposed to run with local resources.

\section{ACADEMIC PERFORMANCE}

\section{RESULT ANALYSIS}

Programs run at a university should not be viewed only through financial standpoint. They should be judged against the quality and marketability of the output. Quality should match with the demand of the labor markets - both national and international. The study of the quality in terms of marketability of the output was not possible due to the time and financial constraints. So, the effectiveness of the program has been analyzed with the perspective of the result of the annual examination. This being a cross sectional study, ranking of the Master programs run in PNC has been done only for the academic year when it was observed.

The number of students appeared in the examination relative to the number of students filling out the examination form varies across the subjects. On an average, around $14 \%$ students have dropped out their studies before filling out the examination form. Eighty-nine percent students filling out the examination form have appeared in the examination. Of this, most of the students appeared in the examination partially. On an aggregate, around $9 \%$ students filling out the examination form have got through their examination. The number of students dropped out before filling out the examination form is greater in the first year than in the second year. The number of absentees in the second year is less than in the first year. In all subjects excepting the Political Science, results of the second year is better than that of the first year. Annual examination results of 
both years excepting few subjects like Geography, Nepali, History and Political Scierrce, are not satisfactory in the observed academic year. The pass percentage in the first year across the subjects varies from $0 \%$ to $60 \%$. In the second year, it does from $3.23 \%$ to $83.33 \%$. All these facts imply that students are more serious in their studies in the second year than in the first year. In general, Master program in this campus is not effective.

\section{InTERdePartmental Performance ANalysis}

For the purpose of interdepartmental performance analysis, $25 \%$ students filling out the examination form were sampled randomly. And then, total marks obtained by each sampled students in the annual examination were extracted from the Marks Ledger. Zero was assigned to those sampled students failing to appear in the examination. The Mann-Whitney $U$ test was run to rank the departments according to the marks scored by the students in the final examination. The pair wise mean ranks of departments show the relative performance position of the concerned department (see Appendix 4.1). The figures given in the row shows the mean rank of the given department relative to the mean rank of the department given in column. For example, the third row shows the mean ranks of Economics Department $\left(\mathrm{MR}_{\mathrm{E}}\right)$ relative to the mean ranks of other departments. If we are comparing performance of Economics Department with Management $\left(M R_{M}\right)$, then for mean rank of Econemics relative to Management, we see the third row of the first column (10.20). For mean rank of Management relative to Economics, we see third column of first row (21.69). The higher mean rank shows the better performance. Thus, the mean ranks of Management and Economics show that performance of Management is better than that of Economics in the observed academic year.

U-statistics given in Appendix 4.2 show hows significantly interdepartmental performance is different. The interdepartmental performance between Management and Geography, Management and Political Science in the first year is not significantly different at $\alpha=.05$. Similarly, in the second year, the interdepartmental performance between Management and History, Management and Political Science, Management and Geography also are not significantly different at the same level. Interdepartmental performance between Sociology and Management, Sociology and English, and Sociology and Geography in the first year is significantly different. Mean rank of Sociology is greater than that of English but smaller than that of Management and Geography. In the same manner, performance of Economics Department is not significantly different from the performance of other department excepting Management. This may be due to the internal assignment in MBS. Performance of English Department is significantly different from the performance of Management, Sociology, History, and Geography. In case of Nepali, its performance is significantly different only from the performance of Management. Performance of History is significantly different from the performance of Management and English. In the first year, performance of Geography is significantly different from Sociology, and Economics. In the same year, its performance is not significantly different from the performance of any departinents. In the first year, performance of 
Mathematics Department is significantly different only from the performance of Management. But in the second year, its performance is significantly different from the performance of Management, Nepali, and Geography.

For ranking the departments, Kruskal-Wallis's test was performed using the Non-parametric Tests Procedures of SPSS. The higher mean rank shows the better performance of the department. Based on the marks obtained in the first year annual examination held in the observed academic year, Geography is the best department. Management is in the second position followed by Political Science. The marks obtained by the students in the first year examination across the department are significantly different.

Table 7: Mean rank of the departments

\begin{tabular}{lrrr}
\hline \multirow{2}{*}{ Subject } & \multicolumn{3}{c}{ Mean Rank } \\
\cline { 2 - 4 } & First Year & Second Year & Aggregate \\
\hline \hline English & 61.87 & 24.28 & 91.29 \\
Nepali & 91.94 & 30.67 & 129.82 \\
Economics & 96.85 & 13.44 & 91.28 \\
Geography & 157.10 & 37.50 & 186.50 \\
History & 112.30 & 27.10 & 132.65 \\
Sociology & 96.77 & 0.00 & 121.90 \\
Mathematics & 69.30 & 12.30 & 71.20 \\
Management & 152.69 & 45.47 & 200.35 \\
Political Science & 131.60 & 40.00 & 184.14 \\
Chi-square & $36.577^{* *}$ & $28.322^{* *}$ & $66.13^{* *}$ \\
\hline \hline
\end{tabular}

**Highly significant.

According to the scores of the second year, Management is in the first position, and Political Science is in the second. Overall, performance of Management faculty is the best one. Geography has held second and Political Science has third position. History, Sociology, Nepali are mediocre. Economics, English and Mathematics fall in the lower band of the performance among the nine departments. The scores in both first year and second year examinations are significantly different across the nine departments. Thus, the significant difference in scores across the departments implies that there is no consistency in the quality of education imparted by different departments.

\section{CONCLUSIONS}

Input cost exclusive to the administrative overhead is Rs. 4,731 in the first year and Rs. 14,917 in the second year. It ranges from Rs. 424 to Rs. 94,313 in the first year and from Rs. 4,820 to Rs.50,031 in the second year across the departments. Similarly, the input cost inclusive of the administrative overhead varies from Rs. 530 to Rs. 117,891 in the first year and from Rs. 6,025 to 62,539 in the second year. On the average, it is Rs. 5,914 in the first year and Rs. 18,647 in the second year. In the same manner, output cost exclusive of the overhead expenses varies from Rs. 13,209 to Rs. 576,720 in the first year and from Rs. 
32,411 to Rs. 685,145 in the second year. Average output cost is Rs. 127,440 in the first year and Rs. 66,243 in the second year. Output cost inclusive of administrative overhead across the departments ranges from Rs. 16.511 to Rs. 720,900 in the first year and from Rs. 40,514 to Rs. 856,432 in the second year. Overall, it is Rs. 159,300 in the first year and Rs. 82,800 in the second year. All these facts imply that Degree programs run in PNC are not cost effective.

Both gross and net cost recovery rates based on the operation cost exclusive of the administrative overhead are below $100 \%$. On an aggregate, average gross cost recovery rate is $52.45 \%$ and net cost recovery rate is $18.96 \%$. Similarly, average gross recovery rate based on the operation cost inclusive of the administrative overhead is $41.96 \%$. But net recovery rate is $15.17 \%$. Thus, Degree programs run in PNC are not financially sustainable.

On an aggregate, around $9 \%$ students filling out the examination form have got through their examination. The pass percent across the departments varies from $0 \%$ to $60 \%$ in the first year and from $3.23 \%$ to $83.33 \%$ in the second year. These facts show that some programs are academically effective and some are not. Kruskal-Wallis test results further bolster this conclusion. This test shows that the scores across the departments in the first year, the second year and in aggregates are significantly different. The highly significant difference in the scores across the departments concludes that quality of education imparted by different departments varies significantly in the observed academic year.

\section{ACKNOWLEDGEMENTS}

I am highly indebted to the Campus Chief, Account Controller and administrative staff of Degree program for their kind cooperation in exploring the data required for this study. Similarly, I am grateful to the unknown referee whose constructive comments gave this article the final shape. Finally, I would like to thank Dr. Rebati Prasad Neupane for language editing and correction.

\section{WORKS CITED}

Baral, Keshar J. (2004). "Academic Problems of Prithivi Narayan Campus and Their Minimization." A discussion paper presented at the symposium organized by Free Student Union, Prithivi Narayan Campus, Pokhara.

Lomax, Richard G. (1998). Statistical Concepts: A Second Course for Education and the Behavioral Science. Mahwah, New Jersey: Lawrence Erlbaum Associates, Publishers.

NPC. (2002). The Tenth Plan, 2002-2007. Kathmandu: NPC.

Task Force for Regional Cluster Development Programme Management Plan (1997). Management Plan for Cluster Development Program in Western Development Region, pt. one. Higher Education Project, Tribhuvan University.

The Twenty-Year Strategic Vision Preparation Team (2000). Tribhuvan University: The Strategic Vision for Twenty Years. Higher Education Project, Tribhuvan University. 


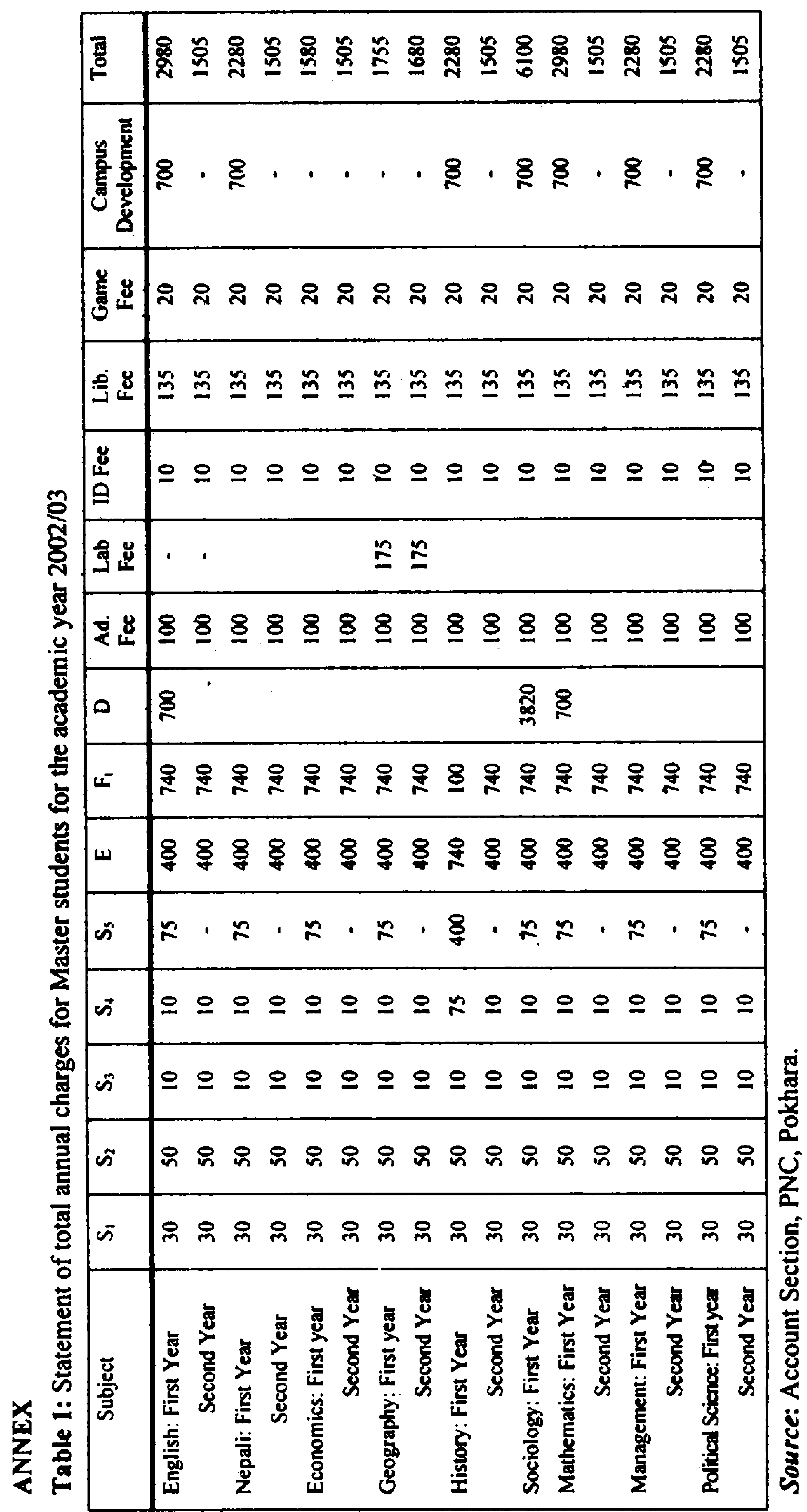


Table - 2: Revenue raised from students in the academic year 2002/03

\begin{tabular}{|c|c|c|c|c|c|c|}
\hline Subjecti & $N_{s}$ & $x$ & Rg & $\mathbf{R}_{\mathbf{c}}$ & $\mathbf{R}_{\mathbf{n}}$ & $N_{p}$ \\
\hline English: First Year & 99 & 2980 & 295020 & 141025 & 153995 & - \\
\hline Second Year & 33 & 1505 & 79765 & 38615 & 41150 & 3 \\
\hline Subtotal & & & 374785 & 179640 & 195145 & 3 \\
\hline Nepali: First Year & 49 & 2280 & 111720 & 35575 & 76145 & 4 \\
\hline Second year & 24 & 1505 & 36120 & 17500 & 18620 & 9 \\
\hline Subtotal & & & 147840 & 53075 & 94765 & 13 \\
\hline Economics: First Year & 43 & 1580 & 67940 & 31385 & 36555 & - \\
\hline Second Year & 35 & 1505 & 52675 & 25305 & 27370 & 1 \\
\hline Subtotal & & & 120615 & 56690 & 63925 & 1 \\
\hline Geography: First Year & 7 & 1755 & 12285 & 4765 & 7520 & 3 \\
\hline Second Year & 12 & 1680 & 20160 & 8380 & 11780 & 10 \\
\hline Subttotal & & & 32445 & 13145 & 19300 & 13 \\
\hline History: First Year & 13 & 2280 & 29640 & 9695 & 19945 & 1 \\
\hline Second Year & 9 & 1505 & 13545 & 6655 & 6890 & 5 \\
\hline Subtotal & & & 43185 & 16350 & 26835 & 6 \\
\hline Sociology: First Year & 467 & 6100 & 2848700 & 2121285 & 727415 & 15 \\
\hline Mathematics: Firs Year & 11 & 2980 & 32780 & 15505 & 17275 & - \\
\hline Second Year & 20 & 1505 & 30100 & 14460 & 15640 & 3 \\
\hline Subtotal & & & 62880 & 29965 & 32915 & 3 \\
\hline Management: First Year & 158 & 2280 & 360240 & 114530 & 245710 & 4 \\
\hline Second Year & 88 & 1505 & 132440 & 63920 & 68520 & 21 \\
\hline Subtotal & & & 492680 & 178450 & 314230 & 25 \\
\hline Political Science: First Year & 15 & 2280 & 34200 & 10845 & 23355 & 5 \\
\hline Second Year & 21 & 1505 & 31605 & 15035 & 16570 & 7 \\
\hline Subtotal & & & 65805 & 25880 & 39925 & 12 \\
\hline Total. & & & 4188935 & 1674480 & 1514455 & 91 \\
\hline
\end{tabular}


Table 3: Student statistics for the academic year 2002/03

\begin{tabular}{|c|c|c|c|c|c|c|c|c|c|}
\hline & \multirow[t]{2}{*}{$\mathbf{N}_{\mathbf{s}}$} & \multicolumn{2}{|c|}{$\mathrm{N}_{\mathrm{F}}$} & \multicolumn{2}{|c|}{$N_{A}$} & \multicolumn{2}{|c|}{$\mathbf{N}_{\mathbf{E}}$} & \multicolumn{2}{|c|}{$N_{p}$} \\
\hline & & No. & $\%$ & No. & $\%$ & No. & $\%$ & No. & $\%$ \\
\hline English: First Year & 99 & 83 & 83.84 & $: 5$ & 18.07 & 68 & 81.93 & - & - \\
\hline Second Year & 53 & 51 & 96.23 & 9 & 17.65 & 42 & 82.35 & 3 & 5.88 \\
\hline Subtotal & 152 & 134 & 88.16 & 24 & $\cdot 17.91$ & 110 & 82.09 & 3 & 2.24 \\
\hline Nepati: First Year & 49 & 43 & 87.76 & 4 & 9.30 & 39 & 90.70 & 4 & 9.30 \\
\hline Second Year & 24 & 24 & 100.00 & 1 & 4.17 & 23 & 95.83 & 9 & 37.50 \\
\hline Subtotal & 73 & 67 & 91.78 & 5 & 7.46 & 62 & 92.54 & 13 & 19.40 \\
\hline Economics: First Year & 43 & 31 & 72.09 & 7 & 22.58 & 24 & 77.42 & $\cdot$ & - \\
\hline Second Year & 35 & 31 & 88.57 & 6 & 19.35 & 25 & 80.65 & 1 & 3.23 \\
\hline Subtotal & 78 & 62 & 79.49 & 13 & 20.97 & 49 & 79.03 & 1 & 1.61 \\
\hline Geography: First Year & 7 & 5 & 71.43 & I & 20.00 & 4 & 80.00 & 3 & 60.00 \\
\hline Second Year & 12 & 12 & 100.00 & 1 & 8.33 & 11 & 91.67 & 10 & 83.33 \\
\hline Subtotal & 19 & 17 & 89.47 & 2 & 11.76 & 15 & 88.24 & 13 & 76.47 \\
\hline History: First Year & 13 & 8 & $6 \mathrm{~T} .54$ & 1 & 12.50 & 7 & 87.50 & 1 & 12.50 \\
\hline Second Year & 9 & 9 & 100.00 & $\mathbf{1}$ & 11.11 & 8 & 88.89 & 5 & 55.56 \\
\hline Subtotal & 22 & 17 & 77.27 & 2 & 11.76 & 15 & 88.24 & 6 & 35.29 \\
\hline Sociology: First Year & 467 & 432 & 92.51 & 47 & 10.88 & 385 & 89.12 & 15 & 3.47 \\
\hline Subtotal & 467 & 432 & 92.51 & 47 & 10.88 & 385 & 89.12 & 15 & 3.47 \\
\hline Mathematics: First Year & 11 & 7 & 63.64 & 1 & 14.29 & 6 & 85.71 & - & - \\
\hline Second Year & 20 & 20 & 100.00 & 3 & 15.00 & 17 & 85.00 & 3 & 15.00 \\
\hline Subtotal & 31 & 27 & 87.10 & 4 & 14.81 & 23 & 85.19 & 3 & 11.11 \\
\hline Political Science: & & & & & & & & & \\
\hline First Year & 15 & 14 & 93.33 & l & 7.14 & 13 & 92.86 & 5 & 35.71 \\
\hline Second Year & 21 & 20 & 95.24 & 2 & 10.00 & 18 & 90.00 & 7 & 35.00 \\
\hline Subtotal & 36 & 34 & 94.44 & 3 & 8.82 & 31 & 91.18 & 12 & 35.29 \\
\hline Total & 1124 & 962 & 85.59 & 109 & 11.33 & 853 & 88.67 & 91 & 9.46 \\
\hline
\end{tabular}

Source: Academic Administration Section, Degree Program, PNC.

Note: $\mathrm{N}_{\mathrm{F}}=$ number of students filling out the examination form

$\mathbf{N}_{\mathrm{A}}=$ number of students absent in all subjects

$N_{E}=$ number of students appeared in the examination 
Table 4: Pairwise mean ranks of departments in the academic year 2002/03.

\begin{tabular}{|c|c|c|c|c|c|c|c|c|c|}
\hline & $\mathrm{MR}_{\mathrm{M}}$ & $\mathrm{MR}_{\mathrm{s}}$ & $\mathbf{M R}_{\mathrm{E}}$ & $\mathrm{MR}_{\mathrm{EN}}$ & $M R_{N}$ & $M R_{H}$ & $\mathbf{M R}_{\mathbf{G}}$ & $\mathbf{M R}_{\mathbf{p}}$ & $M R_{M T}$ \\
\hline \multicolumn{10}{|l|}{$\begin{array}{l}\text { First } \\
\text { Year }\end{array}$} \\
\hline $\mathbf{M} \mathbf{R}_{M}$ & - & 107.98 & 2.1 .69 & 31.17 & 20.08 & 17.42 & 15.08 & 15.96 & 17.81 \\
\hline$M R_{s}$ & 66.70 & - & 66.03 & 73.82 & 65.22 & 63.12 & 62.02 & 62.65 & 64.20 \\
\hline$M R_{E}$ & 10.20 & 65.60 & - & 19.30 & 9.80 & 7.50 & 6.70 & 7.40 & 8.85 \\
\hline$M R_{E N}$ & 11.82 & 49.37 & 12.74 & - & 12.45 & 10.84 & 10.92 & 11.29 & 12.45 \\
\hline$M R_{N}$ & 9.13 & 61.63 & 9.13 & $\$ 7.69$ & - & 6.00 & 5.75 & 6.25 & 7.88 \\
\hline $\mathrm{MR}_{\mathrm{H}}$ & 8.60 & 72.70 & 9.00 & 18.80 & 8.60 & $\cdot$ & 4.20 & 4.80 & 6.60 \\
\hline $\mathrm{MR}_{G}$ & 20.80 & 99.20 & 10.60 & 18.50 & 9.00 & 6.80 & - & 6.10 & 7.10 \\
\hline $\mathrm{MR}_{\mathrm{P}}$ & 16.20 & 84.10 & 9.20 & 17.10 & 8.20 & 6.20 & 4.90 & - & 6.70 \\
\hline$M R_{M T}$ & 6.60 & 46.50 & 6.30 & 12.70 & 5.60 & 4.40 & 3.90 & 4.30 & - \\
\hline \multicolumn{10}{|c|}{$\begin{array}{l}\text { Second } \\
\text { Year }\end{array}$} \\
\hline $\mathbf{M R}_{\mathbf{M}}$ & - & - & 17.50 & 17.22 & 14.19 & 13.28 & 12.39 & 13.39 & 14.50 \\
\hline $\mathrm{MR}_{\mathrm{s}}$ & - & - & - & - & - & - & - & - & - \\
\hline$M R_{E}$ & 4.50 & - & - & 7.00 & 5.31 & 6.38 & 5.56 & 4.50 & 7.17 \\
\hline$M R_{E N}$ & 7.56 & - & 10.78 & - & 7.56 & 7.33 & 6.44 & 5.83 & 8.78 \\
\hline$M R_{N}$ & 7.42 & - & 10.42 & 8.67 & - & 6.33 & 5.58 & 5.50 & 7.75 \\
\hline $\mathbf{M R}_{\mathrm{H}}$ & 7.40 & - & 8.00 & 7.80 & 5.60 & - & 4.80 & 5.10 & 6.40 \\
\hline $\mathbf{M R}_{\mathbf{G}}$ & 10.60 & - & 9.30 & 9.40 & 6.50 & 6.20 & - & 6.40 & 7.10 \\
\hline$M R_{p}$ & 9.83 & - & 11.50 & 11.25 & 7.50 & 6.75 & 5.67 & - & 8.50 \\
\hline $\mathrm{MR}_{M T}$ & $3: 00$ & - & 6.70 & 5.20 & 3.90 & 4.60 & 3.90 & 3.00 & - \\
\hline
\end{tabular}

Note:

$M R_{M}=$ mean rank in Management

$M R_{S}=$ mean rank in Socialogy

$\mathrm{MR}_{\mathrm{E}}=$ mean rank in Economics

$M R_{E N}=$ mean rank in English

$M R_{N}=$ mean rank in Nepali

$M R_{H}=$ mean rank in History

$M R_{G}=$ mean rank in Geogrpahy

$M R_{P}=$ mean rank in Political Science

$\mathrm{MR}_{\mathrm{MT}}=$ mean rank in Mathematics 
Table 5: Pairwise mean ranks of departments in the academic year 2002/03.

\begin{tabular}{|c|c|c|c|c|c|c|c|c|c|}
\hline & $\mathbf{M R}_{M}$ & $\overline{M R}_{s}$ & $\mathbf{M R}_{\mathrm{E}}$ & $\overline{M R_{E N}}$ & $\mathrm{MR}_{\mathrm{N}}$ & $\mathrm{MR}_{\mathrm{H}}$ & $\mathrm{MR}_{\mathrm{G}}$ & $\mathbf{M R}_{\mathbf{P}}$ & $\mathrm{MR}_{\mathrm{MT}}$ \\
\hline $\begin{array}{l}\text { First } \\
\text { Year }\end{array}$ & & & & & & & & & \\
\hline $\mathbf{M R}_{M}$ & 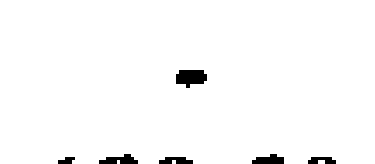 & & & & & & & & \\
\hline $\mathbf{M} \mathbf{R}_{\mathbf{s}}$ & $\begin{array}{c}689.50 \\
(000)\end{array}$ & $\begin{array}{l}- \\
-\end{array}$ & & & & & & & \\
\hline $\mathbf{M} \mathbf{R}_{\mathrm{E}}$ & $\begin{array}{l}47.00 \\
(.003)\end{array}$ & $\begin{array}{l}601.00 \\
(.972)\end{array}$ & - & & & & & & \\
\hline $\mathbf{M R}_{\mathrm{EN}}$ & 34.50 & 748.00 & 52.00 & - & & & & & \\
\hline$M R_{N}$ & 37.00 & $\begin{array}{l}(.044) \\
457.00\end{array}$ & $\begin{array}{l}.048) \\
37.00\end{array}$ & 46.50 & $\bullet$ & & & & \\
\hline & $(.007)$ & $(.792)$ & $(.790)$ & $(.117)$ & & & & & \\
\hline$M R_{H}$ & $\begin{array}{l}28.00 \\
(.047)\end{array}$ & $\begin{array}{c}256.50 \\
(.565)\end{array}$ & $\begin{array}{l}20.00 \\
(.540)\end{array}$ & $\begin{array}{l}16.00 \\
(.025)\end{array}$ & $\begin{array}{l}12.00 \\
(.241)\end{array}$ & - & & & \\
\hline$M R_{G}$ & $\begin{array}{l}41.00 \\
(.197)\end{array}$ & $\begin{array}{l}124.00 \\
(.025)\end{array}$ & $\begin{array}{l}12.00 \\
(.111)\end{array}$ & $\begin{array}{l}17.50 \\
(.032)\end{array}$ & $\begin{array}{l}10.00 \\
(.142)\end{array}$ & $\begin{array}{c}6.00 \\
(.173)\end{array}$ & - & & \\
\hline $\mathbf{M R}_{P}$ & $\begin{array}{l}64.00 \\
(.957)\end{array}$ & $\begin{array}{l}199.50 \\
(.197)\end{array}$ & $\begin{array}{l}19.00 \\
(.461)\end{array}$ & $\begin{array}{l}24.50 \\
(.101)\end{array}$ & $\begin{array}{l}14.00 \\
(.379)\end{array}$ & $\begin{array}{c}9.00 \\
(.465)\end{array}$ & $\begin{array}{c}9.50 \\
(.528)\end{array}$ & - & \\
\hline $\mathbf{M} \mathbf{R}_{\mathbf{M T}}$ & $\begin{array}{l}18.00 \\
(.012) \\
\end{array}$ & $\begin{array}{r}217.50 \\
(.287) \\
\end{array}$ & $\begin{array}{r}16.50 \\
(.297) \\
\end{array}$ & $\begin{array}{l}46.50 \\
(.763) \\
\end{array}$ & $\begin{array}{r}13.00 \\
(.305) \\
\end{array}$ & $\begin{array}{r}7.00 \\
(.251) \\
\end{array}$ & $\begin{array}{r}4.50 \\
(.093) \\
\end{array}$ & $\begin{array}{r}6.50 \\
(.209) \\
\end{array}$ & - \\
\hline $\begin{array}{l}\text { Second } \\
\text { Year }\end{array}$ & & & & & & & & & \\
\hline $\begin{array}{l}\mathbf{M R}_{\mathbf{M}} \\
\text { MR }_{\mathbf{S}}\end{array}$ & - & - & & & & & & & - \\
\hline $\mathbf{M} \mathbf{R}_{E}$ & $\begin{array}{l}00.00 \\
(.000)\end{array}$ & $=$ & - & & & & & & \\
\hline$M R_{E N}$ & $\begin{array}{l}23.00 \\
(.003)\end{array}$ & - & $\begin{array}{l}20.00 \\
(.119)\end{array}$ & - & & & & & \\
\hline $\mathbf{M} \mathbf{R}_{N}$ & $\begin{array}{l}23.50 \\
(.042)\end{array}$ & - & $\begin{array}{c}6.50 \\
(.022)\end{array}$ & $\begin{array}{l}23.00 \\
(.636)\end{array}$ & - & & & & \\
\hline $\mathbf{M R}_{\mathbf{H}}$. & $\begin{array}{l}22.00 \\
(.086)\end{array}$ & - & $\begin{array}{l}15.00 \\
(.451)\end{array}$ & $\begin{array}{l}21.00 \\
(.840)\end{array}$ & $\begin{array}{l}13.00 \\
(.712)\end{array}$ & - & & & \\
\hline $\mathbf{M R}_{\mathbf{G}}$ & $\begin{array}{l}38.00 \\
(.602)\end{array}$ & - & $\begin{array}{c}8.50 \\
(.087)\end{array}$ & $\begin{array}{l}13.00 \\
(.203)\end{array}$ & $\begin{array}{l}12.50 \\
(.647)\end{array}$ & $\begin{array}{c}9.00 \\
(.459)\end{array}$ & - & & \\
\hline$M R_{p}$ & $\begin{array}{l}38.00 \\
(.286)\end{array}$ & - & $\begin{array}{l}00.00 \\
(.002)\end{array}$ & $\begin{array}{c}7.50 \\
(.021)\end{array}$ & $\begin{array}{l}12.00 \\
(.337)\end{array}$ & $\begin{array}{l}10.50 \\
(.409)\end{array}$ & $\begin{array}{l}13.00 \\
(.715)\end{array}$ & - & \\
\hline$M R_{M T}$ & $\begin{array}{c}000 \\
(.001)\end{array}$ & - & $\begin{array}{l}18.50 \\
(.817)\end{array}$ & $\begin{array}{l}11.00 \\
(.117)\end{array}$ & $\begin{array}{c}4.50 \\
(.050)\end{array}$ & $\begin{array}{c}8.00 \\
(.316)\end{array}$ & $\begin{array}{c}4.50 \\
(.085)\end{array}$ & $\begin{array}{l}00.00 \\
(.006)\end{array}$ & - \\
\hline
\end{tabular}

Note:

$M R_{M}=$ mean rank in Management

$M R_{S}=$ mean rank in Socialogy

$M R_{E}=$ mean rank in Economics

$M R_{E N}=$ mean rank in English

$\mathrm{MR}_{\mathrm{N}}=$ mean rank in Nepali

$M R_{H}=$ mean rank in History

$M R_{G}=$ mean rank in Geogrpahy

$M R_{P}=$ mean rank in Political Science

$M R_{M T}=$ mean rank in Mathematics 